\title{
Evaluasi Kualitas Organoleptik Mayonnaise Berbahan Dasar Kuning Telur yang Mendapatkan Suplementasi Tepung Purslane (Portulaca oleracea)
}

\author{
The Sensory Quality Evaluation of Mayonnaise Based on Egg Yolk Supplemented with Purslane Meal \\ (Portulaca Oleracea)
}

L. R. Kartikasari, B. S. Hertanto, \& A. M. P. Nuhriawangsa

Program Studi Peternakan, Fakultas Pertanian Universitas Sebelas Maret

Jl. Ir. Sutami 36A, Surakarta, Indonesia 57126

Email Koresponden author: lilikretna@staff.uns.ac.id

\begin{abstract}
The aim of this research was to evaluate sensory quality of mayonnaise made with egg yolks produced from laying hens fed diets supplemented with purslane meal. The experimental design was a one way classification with five mayonnaise treatments. The treatments included mayonnaise with egg yolks supplemented with $0 \%(\mathrm{P} 0), 2 \%(\mathrm{P} 1), 4 \%(\mathrm{P} 2), 6 \%(\mathrm{P} 3)$, and $8 \%$ (P4) purslane meal. This study used 30 semi-trained panelists to evaluate sensory quality of mayonnaise using a 9-point hedonic scale. Data was analysed using the analysis of variance and if there was any significant difference among treatments, then the analysis was continued using Tukey's test. The results showed that the use of egg yolks from laying hens fed diets supplemented with purslane meal up to a level of $8 \%$ did not significantly change color, texture, creamy, aroma, taste, taste and overall acceptance of mayonnaise. The average score of perception of sensory attributes was between 5 (neither like nor dislike) and 6 (slightly like). It can be concluded that mayonnaise made with egg yolks produced from brown laying hens fed diets supplemented with purslane meal up to a level of $8 \%$ did not negatively affect the sensory quality of mayonnaise.
\end{abstract}

Keywords: purslane, egg yolk, mayonnaise, sensory quality

\section{PENDAHULUAN}

Strategi pemberian pakan merupakan salah satu upaya yang dapat ditempuh untuk meningkatkan kandungan nutrisi dan kualitas telur ayam (Yuwanta, 2010). Telur sebagai bahan pangan yang bergizi dapat dijadikan sebagai bahan pangan fungsional yang bermanfaat bagi kesehatan, yaitu antara lain melalui upaya peningkatan kandungan asam lemak omega-3. Asam lemak omega-3, khususnya eicosapentaenoic acid (EPA) dan docosahexaenoic acid (DHA) merupakan salah satu asam lemak essensial yang mempunyai manfaat positif pada kesehatan manusia (KrisEtherton et al., 2002), seperti menurunkan resiko Coronary Hearth Desease (CHD). Telur kaya asam lemak omega-3 tersebut dapat dihasilkan dengan memodifikasi pakan ayam petelur melalui suplementasi bahan pakan yang kaya akan asam lemak omega-3 (Lawlor et al., 2010; Gakhar et al., 2012).

Asam lemak omega-3 dapat ditemukan pada sumber hewani seperti tepung ikan dan minyak ikan akan tetapi penggunaan bahan-bahan tersebut mempunyai respon negatif terhadap kualitas sensori telur, seperti berbau amis ikan (Bou et al., 2005). Oleh karena itu, perlu adanya alternatif lain yaitu dengan penambahan asam lemak omega-3 yang berasal dari tanaman seperti flaxseed oil (Kartikasari et al., 2012), canola oil (Rowghani et al., 2007), hempseed oil (Goldberg et al., 2012) dan purslane (Evaris et al., 2015).

Jenis tanaman purslane (Portulaca oleracea) lebih banyak ditemukan di Indonesia dibandingkan sumber tanaman yang lain. Rashed et al., (2004) menyatakan bahwa tanaman purslane mengandung komponen asam lemak omega-3 tertinggi diantara sayuran lain dan mengandung xanthophyl, $\beta$-carotene, folic acid, vitamin C, kalium, kalsium dan berfungsi sebagai antioksidan (Irawan et al., 2003). Tanaman purslane segar mengandung asam lemak omega-3 sebesar $400 \mathrm{mg} / 100 \mathrm{~g}$, alpha-tocopherol 12,2 $\mathrm{mg} / 100 \mathrm{~g}$, and ascorbic acid 26,6 mg; beta-carotene 1,9 mg dan glutathione 14,8 mg (Uddin et al., 2014). Hasil penelitian Kartikasari et al., (2015) mendapatkan bahwa suplementasi asam lemak omega-3 yang bersumber dari tanaman pada ayam petelur dapat meningkatan kualitas warna kuning telur karena adanya xanthophyl dan $\beta$-carotene yang cukup tinggi.

Kuning telur sebagai bahan pembuat produk pangan mempunyai peran sebagai pewarna alami, selain itu kuning 
telur juga bisa digunakan sebagai pengemulsi makanan (Muchtadi et al., 2010; Laca et al., 2010). Peran kuning telur ini dapat diaplikasikan dalam industri pengolahan hasil ternak yaitu mayonnaise (Fauziah et al., 2016). Mayonnaise merupakan emulsi semi padat dari campuran minyak nabati dengan vinegar, gula, garam, mustard dan kuning telur sebagai pengemulsi (Chukwu dan Sadiq, 2008).

Kualitas mayonnaise yang berbahan dasar kuning telur yang disuplementasi tepung purslane kaya asam lemak omega-3 diharapkan meningkatkan kualitas organoleptik dan kandungan asam lemak omega-3. Kualitas mayonnaise antara lain dipengaruhi oleh pengemulsi dan penstabil yang berasal dari kuning telur (Amertaningtyas dan Jaya, 2011). Kuning telur sebagai salah satu pengemulsi yang kuat karena mengandung lesitin yang berikatan dengan protein membentuk lesitoprotein (Winarno dan Koswara, 2002; Siregar et al., 2012). Lesitin mempunyai gugus polar yang berikatan dengan air sedangkan non polar berikatan dengan minyak sehingga dapat mengikat minyak dalam air (Hutapea et al., 2016). Mayonnaise yang berwarna kuning kemerahan lebih disukai oleh konsumen dibandingkan dengan mayonnaise yang berwarna kuning pucat (Wardani, 2012). Rasa dan aroma khas mayonnaise yang asam dapat meningkatkan tingkat kesukaan konsumen terhadap mayonnaise (Evanuarini et al., 2016).

Penelitian terkait mayonnaise berbahan dasar kuning telur yang mendapatkan suplementasi tepung purslane belum banyak dilakukan. Berdasarkan uraian di atas dilakukan penelitian untuk mengetahui kualitas organoleptik mayonnaise berbahan dasar kuning telur dari hasil perlakuan ayam petelur yang mendapatkan suplementasi pakan tepung purslane.

\section{MATERI DAN METODE}

\section{Bahan Penelitian}

Sebanyak 30 sampel kuning telur (10 kuning telur per perlakuan) yang dihasilkan dari ayam petelur coklat strain Hy-line brown pada pemeliharaan hari ke-29 yang mendapatkan perlakuan pakan berupa suplementasi tepung purslane sebanyak $0,2,4,6,8 \%$ di dalam pakan basal. Pakan basal tersusun atas jagung kuning, dedak padi, bungkil kedelai, bungkil kelapa, minyak sawit, tepung kapur, DCP, L-lysine, DL-metionin, limestone, garam dan premix. Kandungan nutrien pakan perlakuan memenuhi standar kebutuhan yang direkomendasikan SNI (2006), ditampilkan pada Tabel 1.

Komposisi bahan pembuatan mayonnaise diperoleh dari Shen et al., (2011) yang telah dimodifikasi dengan persentase bahan (w/w) sebagai berikut: kuning telur $14 \%$, vinegar $9 \%$, minyak jagung $74 \%$, garam $1 \%$, gula $1 \%$, dan mustard $1 \%$.

\section{Alat Penelitian}

Peralatan yang digunakan untuk membuat mayonnaise diantara lain sendok, baskom, pisau, pengaduk kaca , kompor, panci, timbangan digital scale (ketelitian $0,01 \mathrm{~g}$ ), thermometer, beaker glass (skala $500 \mathrm{~mL}$ ), yolk separator, dan alumunium foil. Alat yang digunakan dalam pengujian organoleptik meliputi sarung tangan, timbangan digital (ketelitian 0,001 g), nampan, pisau, sendok, garpu, pengoles roti dan alat tulis.

\section{Rancangan Penelitian}

Rancangan penelitian yang digunakan dalam penelitian ini adalah Rancangan Acak Lengkap pola searah (Steel dan Torrie, 1995). Lima perlakuan dalam pembuatan Mayonnaise didasarkan pada penggunaan kuning telur yang dihasilkan dari ayam petelur yang mendapat suplementasi tepung purslane sebagai berikut :

$\mathrm{P0}=$ Mayonnaise dengan kuning telur hasil suplementasi $0 \%$ tepung purslane

$\mathrm{P} 1=$ Mayonnaise dengan kuning telur hasil suplementasi $2 \%$ tepung purslane

P2 = Mayonnaise dengan kuning telur hasil suplementasi $4 \%$ tepung purslane

P3 = Mayonnaise dengan kuning telur hasil suplementasi $6 \%$ tepung purslane

$\mathrm{P} 4=$ Mayonnaise dengan kuning telur hasil suplementasi $8 \%$ tepung purslane

\section{Penentuan Panelis}

\section{Prosedur Penelitian}

Panelis yang digunakan sebanyak 30 orang semi terlatih. Jumlah tersebut sudah memenuhi syarat dari suatu metode penelitian. Silalahi (2012), menyatakan bahwa jumlah responden minimum yang digunakan untuk penelitian adalah 30 responden. Untuk panelis tidak terlatih pengujian kualitas sensori dapat menggunakan anggota

Tabel 1. Kandungan nutrien dalam ransum

\begin{tabular}{lcccccc}
\hline Bahan Pakan & \multicolumn{9}{c}{ Level Penambahan Tepung Purslane (\%) } \\
\cline { 2 - 7 } & P0 & P1 & P2 & P3 & P4 & SNI (2006) \\
\hline EM (kkal/kg) & 2828,41 & 2830,61 & 2828,15 & 2831,17 & 2903,91 & Min 2650 \\
Protein kasar (\%) & 16,62 & 16,69 & 16,66 & 16,68 & 16,58 & Min. 16 \\
Lemak kasar (\%) & 6,21 & 6,27 & 6,26 & 6,41 & 7,63 & Maks. 7 \\
Serat kasar (\%) & 3,91 & 4,19 & 4,51 & 4,75 & 4,84 & Maks. 7 \\
Kalsium (\%) & 2,94 & 2,94 & 2,95 & 2,95 & 2,95 & $3,25-4,25$ \\
Fosfor tersedia (\%) & 0,36 & 0,37 & 0,37 & 0,36 & 0,36 & Min. 0,32 \\
Lisin (\%) & 0,94 & 0,93 & 0,93 & 0,92 & 0,92 & Min. 0,80 \\
Metionin (\%) & 0,42 & 0,44 & 0,45 & 0,47 & 0,48 & Min. 0,35 \\
\hline
\end{tabular}

Sumber : Dihitung berdasarkan kandungan nutrien bahan pakan. 
panel dengan jumlah berkisar antara $25-100$ orang (Soeharto, 2002). Panelis tersebut dipilih dengan cara memberikan pertanyaan yang berupa kuisioner terlebih dahulu mengenai hal-hal yang berkaitan dengan mayonnaise, baik dari adanya kemungkinan alergi terhdap telur dan produk telur, tingkat kesukaan maupun seringnya mengonsumsi mayonnaise.

\section{Pembuatan Mayonnaise}

Prosedur pembuatan mayonnaise mengikuti Shen et al., (2011) yang telah dimodifikasi (Gambar 1) sebagai berikut: kuning telur dimasukkan dalam beaker glass, kemudian pasteurisasi pada suhu $60{ }^{\circ} \mathrm{C}$ selama 3,5 menit. Setelah dipasteurisasi tambahkan vinegar, mustard, garam dan gula. Semua bahan mayonnaise kecuali minyak jagung selanjutnya dihomogenkan. Minyak jagung ditambahkan secara perlahan-lahan dan diaduk dengan secara manual selama 15 menit (Soeharto, 2013). Emulsi (mayonnaise yang telah jadi) disimpan di dalam beaker glass yang telah ditutup alumunium foil selama 24 jam pada suhu ruang (25$30,8^{\circ} \mathrm{C}$ ) sebelum dilakukan pengujian.

\section{Persiapan Sampel Mayonnaise}

Sampel mayonnaise masing-masing disajikan dalam kontainer kecil sebanyak $3 \mathrm{~g}$ dan disajikan dengan mengoleskan pada potongan roti tawar $(1 \times 1 \mathrm{~cm})$ sebanyak 10 potong. Setiap sampel yang akan diuji diberi kode dengan 3-point digit number yang sudah di random (Kartikasari, 2013).

\section{Tahap Evaluasi Kualitas Organoleptik}

Pada pengujian tingkat kesukaan (consumer preference), panelis yang terpilih diberikan form kesediaan dan diberikan lembar kerja yang berisikan 9-point hedonic scale. Cara mengisinya dengan memberikan tanda centang $(\sqrt{ })$ pada point yang ada, sesuai dengan tingkat penerimaan panelis terhadap sampel yang diuji dari amat sangat tidak senang sampai amat sangat senang (Wichchukit dan O’Mahony, 2015). Panelis melakukan pengujian dengan menyicipi sampel mayonnaise. Setiap selesai pengujian satu sampel, panelis diminta untuk minum air putih dan makan original crackers untuk menetralisir rasa (Kartikasari,

Tabel 2. 9-point hedonic scale pada pengujian organoleptik (consumer acceptance)

\begin{tabular}{cl}
\hline Number & \multicolumn{1}{c}{ Consumer Acceptance } \\
\hline 1 & Amat sangat tidak senang (dislike extremely) \\
2 & Sangat tidak senang (dislike very much) \\
3 & Tidak senang (dislike moderately) \\
4 & Agak tidak suka (dislike slightly) \\
5 & Netral (neither like nor dislike) \\
6 & Agak senang (like slightly) \\
7 & Senang (like moderately) \\
8 & Sangat senang (like very much) \\
9 & Amat sangat senang (like extremely) \\
\hline
\end{tabular}

Sumber : Wichchukit dan O’Mahony (2015)

2013). Urutan pilihan 9-point hedonic scale ditampilkan pada Tabel 2. Definisi dari masing-masing atribut pada pengujian kualitas sensori ditampilkan pada Tabel 3.

\section{Analisis Data}

Data yang diperoleh dari penelitian ini dianalisis menggunakan Analysis of Variance untuk mengetahui adanya pengaruh perlakuan kuning telur hasil suplementasi tepung purslane terhadap mayonnaise yang diamati (Minitab 17, Minitab Inc. 2015). Apabila terdapat pengaruh

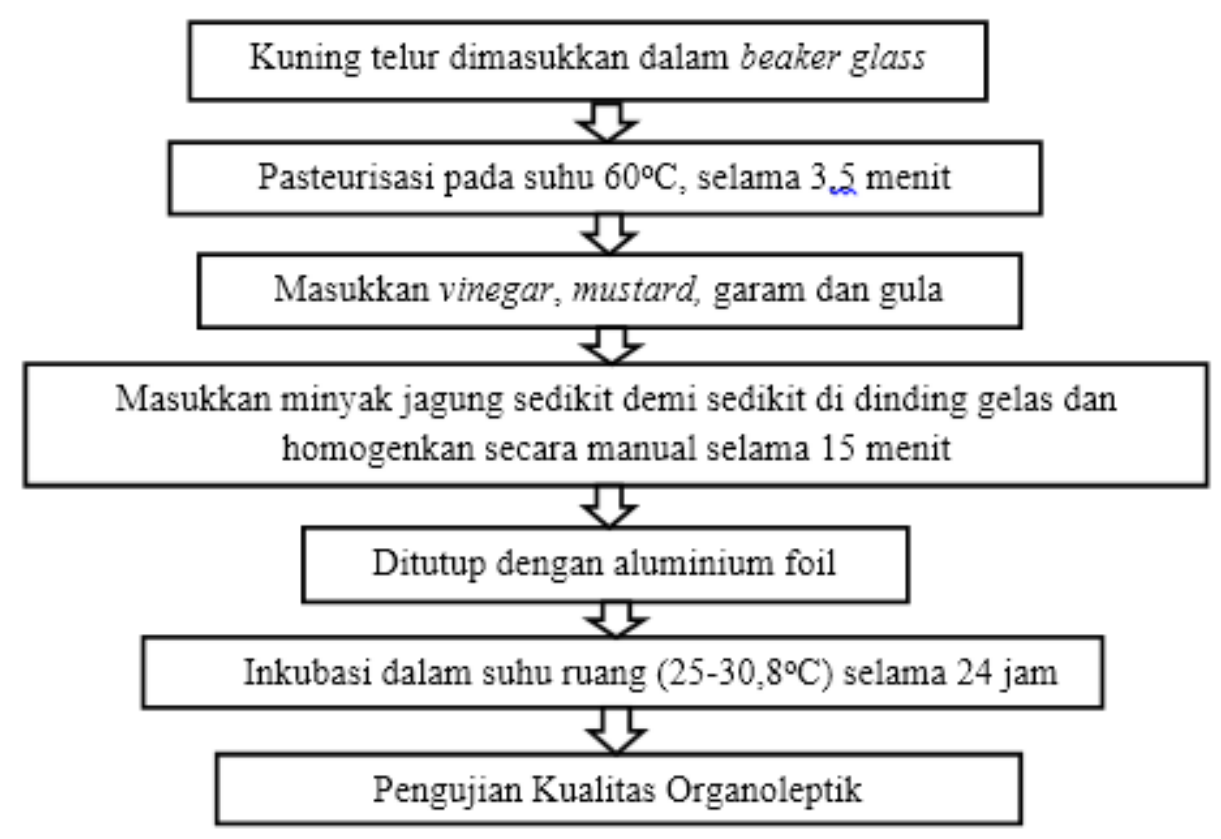

Gambar 1. Pembuatan mayonnaise (Shen et al., 2011 yang dimodifikasi) 
Tabel 3. Deskriptif definisi umum atribut uji organoleptik mayonnaise

\begin{tabular}{ll}
\hline Uji Organoleptik & \multicolumn{1}{c}{ Keterangan } \\
\hline Warna & $\begin{array}{l}\text { Warna kuning yang tampak pada mayon- } \\
\text { naise melalui indera penglihatan1) }\end{array}$ \\
Tekstur & $\begin{array}{l}\text { Penampakan luar khas mayonnaise yang } \\
\text { kental dan lembut2) }\end{array}$ \\
Creamy & $\begin{array}{l}\text { Sesuatu yang berhubungan dengan kara- } \\
\text { kteristik mayonnaise yang lembut dalam } \\
\text { langit-langit mulut2,3) }\end{array}$ \\
Aroma & $\begin{array}{l}\text { Suatu bau yang tercium saat mendekatkan } \\
\text { mayonnaise di hidung4) }\end{array}$ \\
Rasa & $\begin{array}{l}\text { Sensasi rasa dasar mayonnaise yang diper- } \\
\text { oleh dari rasa pada langit-langit mulut2) }\end{array}$ \\
Cita rasa & $\begin{array}{l}\text { Sensori yang dihasilkan dari gabungan rasa } \\
\text { dan aroma pada mayonnaise1) }\end{array}$ \\
Kesukaan secara & $\begin{array}{l}\text { Tingkat kesukaan penerimaan panelis yang } \\
\text { timbul karena hasil dari penilaian warna, } \\
\text { keseluruhan }\end{array}$ \\
& $\begin{array}{l}\text { rasa, aroma, cita rasa, dan off flavor. Timbul } \\
\text { kesukaan terhadap suatu objek yang dira- } \\
\text { sakan5) }\end{array}$ \\
\hline
\end{tabular}

Sumber : 1) Winarno (1993), 2) Laca et al., (2011), 3) Kovalcuks et al., (2016), 4) Lawlor et al., (2010), 5) Shewfelt (2009)

perlakuan maka dilanjutkan dengan uji Tukey untuk mengetahui perbedaan antar mean (rata-rata) perlakuan (Steel dan Torrie, 1995).

\section{HASIL DAN PEMBAHASAN}

Hasil pengujian organoleptik oleh panelis terhadap atribut penilaian karakteristik mayonnaise yang meliputi warna, tekstur, creamy, rasa, aroma, cita rasa dan kesukaan secara keseluruhan ditampilkan pada Tabel 4.

\section{Warna}

Berdasarkan analisis variansi menunjukkan bahwa kesukaan terhadap warna mayonnaise berbahan kuning telur ayam dari hasil perlakuan suplementasi tepung purslane sampai level $8 \%$ tidak berbeda secara nyata (Tabel 4). Ratarata tingkat kesukaan panelis atau konsumen terhadap warna sampel mayonnaise sebesar 5,51 yaitu mengindikasikan agak suka. Hasil penelitian ini sejalan dengan Jaya et al., (2011) yang melaporkan bahwa penggunaan konsentrasi kuning telur dan minyak nabati yang berbeda menghasilkan tingkat kesukaan warna yang tidak berbeda yaitu agak suka. Warna pada makanan menjadi salah satu faktor utama yang dipertimbangkan oleh konsumen dalam memilih suatu produk, karena warna produk merupakan atribut yang pertama kali dilihat oleh konsumen (Wagiyono, 2003).

Penggunaan kuning telur pada pembuatan mayonnaise bukan hanya fungsinya sebagai pengemulsi, tetapi juga sebagai pewarna pada mayonnaise karena adanya pigmen yang memberi warna kuning yaitu xanthophyl (Amertaningtyas dan Jaya, 2011). Menurut Shen et al., (2011), warna yang dihasikan mayonnaise berasal dari kuning telur, minyak nabati dan mustard yang digunakan
Tabel 4. Rata-rata hasil analisis pengujian kesukaan konsumen mayonnaise

\begin{tabular}{|c|c|c|c|c|c|c|}
\hline \multirow[t]{2}{*}{ Parameter } & \multicolumn{5}{|c|}{ Perlakuan } & \multirow[t]{2}{*}{ Signifikan } \\
\hline & P0 & P1 & P2 & P3 & P4 & \\
\hline Warna & 5,97 & 5,47 & 5,63 & 5,33 & 5,13 & NS \\
\hline Tekstur & 5,90 & 5,27 & 5,40 & 5,30 & 5,33 & NS \\
\hline Creamy & 5,90 & 5,67 & 5,37 & 5,47 & 5,43 & NS \\
\hline Aroma & 5,40 & 5,37 & 5,37 & 4,67 & 4,90 & NS \\
\hline Rasa & 5,60 & 5,73 & 5,27 & 5,17 & 5,13 & NS \\
\hline Cita Rasa & 5,70 & 5,47 & 5,23 & 5,13 & 5,33 & NS \\
\hline $\begin{array}{l}\text { Kesukaan } \\
\text { Secara } \\
\text { keseluruhan }\end{array}$ & 5,90 & 5,47 & 5,50 & 5,17 & 5,43 & NS \\
\hline
\end{tabular}

Keterangan : Mayonnaise dengan kuning telur yang mendapat suplementasi tepung purslane ( $\mathrm{P} 0=0 \%, \mathrm{P} 1=2 \%$, $\mathrm{P} 2=4 \%, \mathrm{P} 3=6 \%$ dan $\mathrm{P} 4=8 \%$ ); NS (not significant)

saat pembuatan mayonnaise. Warna mayonnaise yang kuning kemerahan lebih disukai konsumen dibandingkan dengan warna mayonnaise yang kuning pucat (Wardani, 2012). Konsumen akan tertarik pada warna mayonnaise yang memiliki warna dengan intensitas tinggi dibandingkan dengan intensitas rendah (Astriana, 2013).

Hasil penelitian Kartikasari et al., (2017) mendapatkan bahwa intensitas warna kuning telur meningkat dengan penambahan tepung purslane sampai level $8 \%$ dalam pakan, namun demikian belum cukup memberikan perbedaan terhadap intensitas warna kuning mayonnaise sehingga tingkat kesukaan konsumen terhadap warna mayonnaise relatif sama. Hal ini kemungkinan disebabkan oleh bahan-bahan pembuat mayonnaise yang lain ikut berperan dalam menghasilkan warna mayonnaise.

\section{Tekstur}

Analisis variansi menunjukan bahwa kesukaan terhadap tekstur mayonnaise dari kuning telur ayam yang mendapatkan suplementasi tepung purslane sampai level $8 \%$ tidak berbeda secara nyata $(\mathrm{p}>0,05)$ dibandingkan dengan tekstur mayonnaise dari kuning telur tanpa suplementasi tepung purslane (Tabel 4). Hal ini kemungkinan dikarenakan pembentukan tekstur yang sama antar perlakuan (Shen et al., 2011), sehingga kesukaan konsumen terhadap tekstur mayonnaise relatif sama.

Penilaian rata-rata kesukaan konsumen terhadap tekstur mayonnaise dari semua perlakuan yaitu sebesar 5,44 (cenderung agak suka). Penilaian konsumen yang agak suka terhadap tekstur kemungkinan tekstur yang dihasilkan mendekati tekstur khas mayonnaise yaitu semi padat (Winarno, 1997). Hasil ini sesuai dengan penelitian (Amertaningtyas dan Jaya, 2011) yang melaporkan tingkat kesukaan konsumen agak suka dengan nilai 5,69, terhadap tekstur mayonnaise yang cukup kental. Tekstur mayonnaise yang sangat kental dan lembut lebih disukai konsumen dibandingkan tekstur yang encer (Tranggono et al., 1989).

\section{Creamy}

Hasil analisis variansi menunjukkan bahwa penggunaan kuning telur ayam yang mendapatkan 
suplementasi tepung purslane sampai level 8\% tidak berpengaruh $(\mathrm{p}>0,05)$ terhadap kesukaan creamy mayonnaise (Tabel 4). Hal ini kemungkinan disebabkan karena penggunaan kuning telur yang mendapatkan suplementasi tepung purslane pada persentase yang sama. Hal ini sesuai dengan hasil penelitian Kovalcuks et al., (2016) yang mendapatkan bahwa mayonnaise mempunyai tingkat kesukaan konsumen creamy berbeda jika persentase kuning telur yang ditambahkan berbeda.

Berdasarkan uji kesukaan mayonnaise menunjukan bahwa kesukaan konsumen pada creamy mayonnaise yaitu agak suka $(5,57)$. Penilaian tersebut kemungkinan dipengaruhi hasil mayonnaise yang agak lembut. Soeharto (2013) menyatakan bahwa semakin creamy mayonnaise maka tingkat kesukaan konsumen semakin tinggi. Tingkat kehalusan mayonnaise berpengaruh terhadap creamy mayonnaise, kesukaan konsumen terhadap creamy mayonnaise apabila mayonnaise yang dihasilkan lebih halus karena lebih mudah untuk dikunyah dan ditelan (Pradhananga dan Adhikari, 2014).

\section{Aroma}

Hasil analisis variansi menunjukkan bahwa tidak terdapat perbedaan secara nyata $(\mathrm{p}>0,05)$ dari mayonnaise berbahan dasar kuning telur ayam yang mendapatkan suplementasi tepung purslane sampai level $8 \%$ dengan mayonnaise dari kuning telur tanpa penambahan tepung purslane (Tabel 4). Hasil tesebut kemungkinan disebabkan oleh penggunaan kuning telur dan vinegar yang memberikan aroma khas mayonnaise sama sehingga aroma yang dihasilkan juga tidak berbeda. Penggunaan bahan yang sama menghasilkan aroma yang sama pula terhadap mayonnaise (Wenfuu, 2011).

Tingkat kesukaan konsumen terhadap aroma mayonnaise adalah netral $(5,14)$. Hasil penelitian ini sesuai dengan penelitian Wardani (2012) yang menyatakan bahwa konsumen memberikan penilaian biasa saja atau netral terhadap mayonnaise tidak beraroma. Hal ini karena aroma mayonnaise yang dihasilkan tidak sekuat aroma khas mayonnaise. Setyaningsih et al. (2010) berpendapat bahwa aroma menunjukkan sifat sensori yang memerlukan sensitifitas dalam merasa dan mencium makanan. Winarno (1992) menambahkan bahwa aroma makanan dapat membentuk kelezatan dan lebih banyak berhubungan dengan alat indera pembau.

\section{Rasa}

Hasil analisis variansi menunjukkan bahwa penggunaan kuning telur ayam yang mendapatkan suplementasi tepung purslane sampai level 8\% tidak berpengaruh nyata $(\mathrm{p}>0,05)$ terhadap kesukaan rasa mayonnaise (Tabel 4). Tingkat kesukaan konsumen tidak berbeda kemungkinan karena persepsi panelis terhadap rasa yang dihasilkan antar perlakuan mayonnaise relatif sama. Rasa yang dihasilkan pada makanan akan mempengaruhi kesukaan konsumen terhadap makanan yang dimakannya (Winarno dan Koswara, 2002).

Kesukaan konsumen terhadap rasa mayonnaise adalah netral. Hal ini kemungkinan disebabkan adanya rasa hambar atau tidak sekuat rasa khas mayonnaise. Penelitian
Wardani (2012) melaporkan bahwa panelis menilai biasa saja atau netral terhadap rasa mayonnaise yang agak asam dan konsumen menyukai mayonnaise yang berasa lebih asam. Penelitian Evanuarini et al., (2016) menambahkan bahwa penggunaan asam tambahan dalam pembuatan mayonnaise lebih disukai konsumen. Usman et al., (2015) menyatakan bahwa rasa sangat berperan dalam mempengaruhi kesukaan konsumen terhadap produk makanan. Rasa hambar pada makanan menurunkan tingkat kesukaan konsumen (Winarno, 1997).

\section{Cita Rasa}

Hasil analisis variansi menunjukkan bahwa kesukaan konsumen terhadap cita rasa mayonnaise tidak berbeda nyata ( $>00,05)$ antar perlakuan (Tabel 4). Hasil ini sejalan dengan penelitian Irawan et al., (2003) yang menyatakan pemberian suplementasi nabati yang mengandung asam lemak omega-3 tidak memberikan kesan negatif terhadap sensori, sehingga konsumen menerima cita rasa yang dihasilkan dari perlakuan mayonnaise.

Rata-rata nilai kesukaan konsumen terhadap cita rasa mayonnaise sebesar 5,37 yaitu netral. Hal ini disebabkan cita rasa yang dihasilkan tidak sekuat cita rasa khas mayonnaise sehingga tingkat kesukaan konsumen netral mengarah ke agak suka. Winarno (1993) menyatakan bahwa kesukaan konsumen terhadap cita rasa akan meningkat apabila aroma dan rasa asam cukup kuat karena memberikan efek segar saat merasakan mayonnaise.

Pada penelitian ini tingkat kesukaan konsumen terhadap aroma dan rasa mayonnaise juga netral. Winarno dan Koswari (2002) menambahkan bahwa penilaian rasa dan aroma sangat berperan dalam pembentukan cita rasa, sehingga dapat menentukan tingkat kesukaan konsumen terhadap mayonnaise.

\section{Kesukaan Secara Keseluruhan}

Berdasarkan analisis variansi menunjukkan bahwa kuning telur ayam yang mendapatkan suplementasi tepung purslane sampai level 8\% menghasilkan produk mayonnaise dengan tingkat kesukaan secara keseluruhan yang tidak berbeda ( $p>0,05$; Tabel 4$)$.

Rata-rata kesukaan konsumen terhadap kesukaan secara keseluruhan mayonnaise yaitu cenderung agak suka $(5,5)$, yang berarti konsumen menerima mayonnaise kontrol maupun hasil perlakuan kuning telur dengan suplementasi tepung purslane. Hal ini kemungkinan karena mayonnaise yang dihasilkan mendekati karakteristik mayonnaise di pasaran, sehingga mayonnaise relatif disukai oleh konsumen.

Wardani (2012) menyatakan bahwa penilaian organoleptik secara keseluruhan mayonnaise dipengaruhi oleh penilaian suka atau tidak suka konsumen. Pada penelitian ini penilaian tingkat kesukaan panelis terhadap warana, aroma, rasa dan cita rasa mayonnaise hasil perlakuan pada kisaran netral sampai agak suka. Shewfelt (2009) menambahkan bahwa tingkat kesukaan secara keseluruhan atau penerimaan panelis terhadap sampel yang diuji merupakan hasil dari penilaian warna, rasa, aroma, cita rasa, dan off flavor. 


\section{KESIMPULAN}

Mayonnaise berbahan dasar kuning telur yang dihasilkan dari ayam petelur yang mendapatkan suplementasi tepung purslane sampai level $8 \%$ tidak memberikan pengaruh yang negatif terhadap kualitas organoleptik mayonnaise.

\section{DAFTAR PUSTAKA}

Amertaningtyas, D., \& F. Jaya. 2011. Sifat fisiko-kimia mayonnaise dengan berbagai tingkat konsentrasi minyak nabati dan kuning telur ayam buras. Jurnal Ilmu Ilmu Peternakan 21(1):1-6.

Astriana, Y. 2013. Peningkatan intensitas warna kuning telur dan kadar omega-3 pada burung puyuh yang diberi pakan undur-undur laut. Skripsi. Sarjana Sains Biologi. Universitas Negeri Semarang. Semarang.

Bou, R., F. Guardiola, A. C. Barroeta, \& R. Codony. 2005. Effect of dietary fat sources and zinc and selenium supplements on the composition and consumer acceptability of chicken meat. Poultry Science 84:11291140.

Chukwu, O., Y. Sadiq. 2008. Storage stability of groundnut oil and soya oil-based mayonnaise. Journal of Food Technology 6(5): 217-220.

Evaniarini, H., Nurliyani, Indratiningsih, \& P. Hastuti. 2016. Kestabilan emulsi dan karakteristik sensoris low fat mayonnaise dengan menggunakan kefir sebagai emulsifier replacer. Jurnal Ilmu dan Teknologi Hasil Ternak 11(2):53-59.

Evaris, E., L. A. Sarmiento-Franco, J. C. Segura-Correa, \& C. M. Capetillo-Leal. 2015. Effect of dietary inclusion of purslane (Portulaca oleracea l.) on yolk omega-3 fatty acids content, egg quality and productive performance of Rhode Island Red hens. Tropical and Subtropical Agroecosystems 18:33-38.

Fauziah, C. I., A. H. Zaibunnisa, H. Osman, \& W. M. Aida. 2016. Physicochemical analysis of cholesterol-reduced egg yolk powder and its application in mayonnaise. International Food Research Journal 23(2):575-582.

Gakhar, N., E. Goldberg, M. Jing, R. A. Gibson, \& J. D. House. 2012. Effect of feeding hemp seed and hemp seed oil on laying hen performance and egg yolk fatty acid content: Evidence of their safety and efficacy for laying hen diets. Poultry Science 91(3):701-711.

Goldberg, E. M., N. Gakhar, D. Ryland, M. Aliani, \& R.A. Gibson. 2012. Fatty acid profile and sensory characteristics of table eggs from laying hens fed hempseed and hempseed oil. Journal of Food Science 77(4):153-160.

Hutapea, C. A., H. Rusmarilin, \& M. Nurminah. 2016. Pengaruh perbandingan zat penstabil dan konsentrasi kuning telur terhadap mutu reduced fat mayonnaise. Jurnal Imu dan Teknologi Pangan 4(3):304-311.

Irawan, D., P. Hariyadi, \& H. Wijaya. 2003. The potency of krokot as functional food ingredients. Indonesian Food and Nutrition Progress 10(1):1-12.

Jaya, F., D. Amertaningtyas, \& H. Tistiana. 2013. Evaluasi mutu organoleptik mayonnaise dengan bahan dasar minyak nabati dan kuning telur ayam buras. Jurnal Ilmu dan Teknologi Hasil Ternak 8(1):30-34.

Kartikasari, L. R. 2013. Omega-3 long chain polyunsaturated fatty acid (n-3 LCPUFA) levels in chicken products follwing consumption of alphalinolenic acid enriched diets. Disertasi. PhD Program. The University of Adelaide, Australia.

Kartikasari, L. R., A. M. P. Nuhriawangsa, B. S. Hertanto, \& W. Swastike. 2015. Effect of supplementation purslane (Portulaca oleracea) as a source of alpha-linolenic acid on production performance and physical quality of egg of laying hens. Animal Production 17(2):149-153.

Kartikasari, L. R., B. S. Hertanto, D. Pranoto, A. M. P. Nuhriawangsa. 2017. Exterior and interior physical quality of egg of laying hens fed diets containing different dietary purslane levels IOP Conf. Series: Materials Science and Engineering 1234567890 193 (2017) 012027 doi:10.1088/1757-899X/193/1/012027.

Kartikasari, L. R., R. J. Hughes, M. S. Geier, S. E. P. Bastian, M. Makrides, \& R. A. Gibson. 2012. Comparison of omega-3 levels in two strains of broilers and layers fed high alpha linolenic acid diets. In: Proceedings of the World's Poultry Science Association, the 23rd Annual Australian Poultry Science Symposium. Sydney, New South Wales. pp. 237-240.

Kovalcuks, A., E. Straumite, \& M. Duma. 2016. The effect of egg yolk oil on the chemical, physical and sensory properties of mayonnaise. Rural Sustainability Research 35:330-337.

Kris-Etherton, P. M., W. S. Harris, \& L. J. Appel. 2002. Fish consumption, fish oil, omega-3 fatty acids, and cardiovascular disease. Circulation 106(21):27472757.

Laca, A., M. C. Sáenz, B. Paredes, \& M. Díaz. 2010. Rheological properties, stability and sensory evaluation of low-cholesterol mayonnaises prepared using egg yolk granules as emulsifying agent. Journal of Food Engineering 97:243-252.

Lawlor, J. B., N. Guadette, T. Dickson, \& J. D. House. 2010. Fatty acid profile and sensory characteristics of table eggs from laying fed diets containing microencapsulated fish oil. Animal Feed Science Technology 156(3-4):97-103.

Muchtadi, T. R., Sugiyono, \& F. Ayustaningwarno. 2010. Ilmu pengetahuan bahan pangan. Cetakan Kedua. CV. Alfabeta. Bogor.

Pradhananga, M., B. Adhikari. 2015. Sensory and quality evaluation of mayonnaise and its effect on storage stability. Sunsari Technical College Journal 2(1):48-53.

Rashed, S., U. Akhter, S. Manohar, \& Z. Sajjad. 2004. Food aid distribution in Bangladesh, FCND briefs 173, International Food Policy Research Institute (IFPRI).

Rowghani, E., M. Arab, S. Nazifi, \& Z. Bakhtiari. 2007. Effect of canola oil on cholesterol and fatty acid composition of egg-yolk of laying hens. Journal Poultry Science 6(2):111-114.

Setyaningsih, D., A. Apriyanto, \& M.P. Sari. 2010. Analisis sensori untuk industri pangan dan agro. Institut 
Pertanian Bogor. Bogor.

Shen, R., S. Luo, \& J. Dong. 2011. Application of aot dextrine for fat substitute in mayonnaise. Food Chemistry 126:65-71.

Shewfelt, R. L. 2009. Introducing food science. CRC-Press.

Silalahi, U. 2012. Metode penelitian sosial. Bandung (ID): PT Refika Aditama.

Soeharto, S. T. 2002. Penilaian organoleptik untuk industri pangan dan hasil pertanian. Bharata Karya Aksara. Jakarta.

Soeharto, S. T. 2013. Teknologi penanganan dan pengolahan telur. Alfabeta. Bandung.

Spence, J. D., D.J.A. Jenkins, \& J. Davignon. 2012. Egg yolk consumption and carotid plaque. Atherosclerosis 224:469-473.

Steel, R. G. D, J. H. Torrie. 1995. Prinsip dan prosedur statistika. Suatu Pendekatan Biometrik. PT. Gramedia Pustaka Utama. Jakarta.

Tranggono, S., A. Haryadi, S. Murdiati, S. Sudarmadji, K. Rahayu, S. Naruki, \& M. Astuti. 1989. Bahan tambahan pangan (food additive). Pusat antar Universitas Pangan dan Gizi. Universitas Gadjah Mada. Yogyakarta.

Uddin, M. K., A. S. Juraimi, M. S Hossain, M. A. U. Nahar, M. E. Ali, \& M.M. Rahman. 2014. Purslane weed (Portulaca oleracea): a prospective plant source of nutrition, omega-3 fatty acid and antioxidant attributes. Scientific World Journal 14(1):1-6.
Usman, N. A., E. Wulandari, \& K. Suradi. 2015. Pengaruh jenis minyak nabati terhadap sifat fisik dan akspetabilitas mayonnaise. Jurnal Ilmu Ternak 15:1-6.

Wagiyono. 2003. Menguji kesukaan secara organoleptik. Departemen Pendidikan Nasional.

Wardani, N. P. 2012. Pemanfaatan ekstrak bunga rosela (Hibiscus sabdariffa L) kaya antioksidan dan pembuatan mayonnaise berbahan dasar minyak kelapa, minyak sawit, dan minyak kedelai. Skripsi. Fakultas Ekologi Manusia. Institut Pertanian Bogor, Bogor.

Wenfuu. 2011. Bahan tambahan makanan antioksidan dan sekuestran. Universitas Hassanudin, Makassar.

Wichchukit, S., M. O’Mahony. 2015. The 9-point hedonic scale and hedonic ranking in food science: some reappraisals and alternatives. Journal Science Food Agriculture 95(11):2167-2178.

Winarno, F. G. 1993. Pangan gizi, teknologi dan konsumen. Gramedia Pustaka Utama. Jakarta.

Winarno, F. G. 1997. Kimia pangan dan gizi. Gramedia Pustaka Utama. Jakarta.

Winarno, F. G., \& Koswara, 2002. Telur, komposisi, penanganan dan pengolahan. M-Brio Press. Jakarta.

Yuwanta, T. 2010. Telur dan kualitas telur. Universitas Gadjah Mada-Press, Yogyakarta. 